\title{
TINDAK TUTUR DALAM TINJAUAN FILSAFAT BAHASA
}

\section{Speech Acts in Language Philosophy}

\author{
Izhar $^{\text {I* }}$ \\ Seftika $^{2}$ \\ I Universitas Negeri Semarang, \\ Semarang, Indonesia. \\ 2 Universitas Muhammadiyah \\ Pringsewu, Lampung, Indonesia. \\ *email: izharhamka@gmail.com
}

Kata Kunci:

Aksiologi I

Epistemologi 2

Ontologi 3

Tindak Tutur4

Keywords:

Axiology 1

Epistemology 2

Ontology 3

Speech Acts 4

\begin{abstract}
Abstrak
Penelitian ini bertujuan untuk mendeskripsikan kajian tindak tutur berdasarkan tinjauan secara ontologi, epistemologi, dan aksiologi. Di dalam penelitian ini digunakan metode kualitatif deskriptif dengan teknik studi pustaka. Berdasarkan hasil penelitian diperoleh informasi bahwa mengkaji tindak tutur secara ontologi berarti mengkaji tindak tutur dari segi konsep atau hakikat, yakni konsep tuturan dan tindakan dalam berbahasa. Mengkaji tindak tutur secara epistemologi berarti mengkaji tindak tutur dari segi proses, prosedur, atau cara kerja tindak tutur tersebut dalam berbahasa. Dan, mengkaji tindak tutur secara aksiologi berarti mengkaji tindak tutur dari segi konsep nilai atau manfaat tindak tutur tersebut dalam berbahasa.
\end{abstract}

\begin{abstract}
This study aims to describe the speech act studies based on an ontology, epistemology, and axiology review. This research used descriptive qualitative method. Then, it applied literature study technique. Based on the results of the study, it was found information that studying speech acts ontologically means reviewing speech acts in terms of concepts or nature, namely the concept of speech and actions in language. Studying speech acts in epistemology means reviewing speech acts in terms of the process, procedure, or the way of speech acts work in language. And, studying the speech act in axiology means studying the speech act in terms of the concept of the value or benefits of the speech act in language.
\end{abstract}

\section{PENDAHULUAN}

Peran bahasa dan kesungguhan berbahasa dalam kehidupan berkomunikasi sangat strategis. Keduanya tidak bisa dipisahkan bagai setali mata uang. Bahasa menjadi ekpsresi tentang apa yang dipikirkan, dirasakan, dan sikapi oleh seseorang. Bahasa bisa menjadi sarana yang bukan saja memberikan informasi tentang yang diekspresikan itu, namun juga menindakkan seseorang untuk melakukan sesuatu. Bahasa yang baik ialah bahasa yang tampak kesungguhannya. Kesungguhan yang dimaksud akan terlihat manakala penutur bahasa maupun lawan tuturnya menyikapi topik pembicaraan yang bukan saja secara lisan tapi juga melalui tindakan. la akan sungguhsungguh merespon hal yang dibicarakan dengan segenap kondisi yang ada pada dirinya. Tidak perduli itu dapat dilakukan dalam tempo sekarang, besok, maupun yang akan datang.

Bahasa disebut juga sebagai fenomena komunikasi. Sebab, bahasa yang dikomunikasikan tidak terlepas dari berbagai sisi sosial dan sisi kultural. Dari sisi sosial, bahasa mencerminkan tatanan sosial yang berada pada suatu masyarakat tertentu. Penutur bahasa, status penutur, dan lokasi penutur menjadi pijakan bahasa yang digunakan Artinya, berbagai tuturan maupun tindakan yang muncul bernar-benar berintegrasi dengan situasi sosial yang ada. Kemudian, dari sisi kultural bahasa dipengaruhi oleh kebudayaan setempat. Bahasa mencerminkan kebudayaan. Penggunaannya tidak akan dapat dipisahkan dari kondisi budaya yang ada. Itulah sebabnya, bahasa tidak pernah terlepas dari budaya di mana bahasa itu lahir. 
Itulah sebabnya, sampai kapanpun bahasa tidak akan pernah terlepas dari tindak tutur sebagai manifestasi interaksi kehidupan nyata di mana seseorang saling berinteraksi dan bertransaksi. Sebab, tindak tutur mempersoalkan keserasian antara tuturan dan tindakan yang digunakan saat berkomunikasi dengan konteks tuturan yang bersifat sensitif. Dikatakan 'sensitif' dikarenakan bilamana seseorang bertutur dengan tidak memandang konteks, maka dipastikan tidak akan terjadi komunikasi yang harmonis antara lawan tutur dan mitra tutur. Jangankan, untuk melakukan tindakan sebagaimana yang diharapkan, tuturan berbalas pun tak akan didapati sebagai wujud interaksi komunikasi.

Itulah, mengapa penguasaan pengetahuan tindak tutur sangat penting dalam kegiatan berkomunikasi. Penutur maupun mitra tutur dapat menata kata atau kalimat untuk strategi komunikasinya dan bahkan keduanya dapat memahami arti komunikasi dengan baik sebagaimana yang diharapkan oleh lawan bicaranya. Hal ini sebagaimana yang dikemukakan oleh Tagor (2008: III), bahwa penguasaan tindak tutur akan membantu seseorang berkomunikasi, baik dalam tingkat intrakultural maupun interkultural. Demikian juga untuk kegiatan-kegiatan formal/profesional maupun kehidupan sehari-hari.

Tindak tutur merupakan salah satu objek kajian pragmatik yang dalam sejarah perkembangannya tidak terlepas dari perkembangan ilmu filsafat bahasa. Filsafat bahasa merupakan disiplin ilmu yang mengintegrasikan antara ilmu filsafat dan ilmu linguistik. Disiplin ilmu ini berusaha mengkaji hakikat dan kedudukan bahasa sebagai kegiatan manusia serta dasar-dasar konseptual dan teoretis linguistik. Filsafat bahasa mencari hakikat ilmu pengetahuan atau hakikat pengetahuan konseptual (id.m.wikipedia.org). Berdasarkan hal tersebut, dapat dipastikan bahwa filsafat bahasa mempelajari bahasa sebagai objek pengantar yang pada akhirnya diperoleh hakikat tentang pengetahuan secara konseptual dan prosedural bahasa tersebut.

Dalam kajian pemerolehan pengetahuan, filsafat mendasarkan pada kajian bidang ontologi, epistemologi, dan aksiologi. Bahrum (2013) mengemukakan bahwa ontologi tentang apa yang ingin diketahui mengenai teori tentang 'ada' dengan perkataan lain bagaimana hakikat objek yang ditelaah sehingga memperoleh pengetahuan. Epistemologi membahas tentang proses memperoleh pengetahuan, dan aksiologi membahas tentang nilai yang berkaitan dengan kegunaan dari pengetahuan yang diperoleh. Merujuk kepada konsep tersebut, dapat diartikan bahwa ontologi mengkaji pengetahuan atau teori dari sudut pandang 'apa', epistemologi mengkaji pengetahuan atau teori dari sudut pandang bagaimana proses atau cara kerjanya, dan aksiologi membahas pengetahuan atau teori dari sudut pandang nilai kegunaan atau manfaat. Tepatnya, Suriasumantri (20l0) mengatakan bahwa ontologi berkaitan dengan objek yang akan ditelaah dan wujud hakiki objek tersebut, epistemologi berkaitan dengan bagaimana proses atau prosedur dalam memperoleh pengetahuan, dan aksiologi berkaitan dengan peruntukkan pengetahuan itu digunakan berdasarkan kaidah moral.

Pengkajian tindak tutur dari segi filsafat sangat penting. Sebab, hakikat, cara kerja, dan fungsi tindak tutur perlu diketahui secara baik. Komunikasi dijalin atas interaksi melalui tuturan dan tindakan. Tuturan dan tindakan tersebut harus dapat dimanifestasikan dalam bentuk kesungguhan atau kerjasama untuk memperoleh keefektifan komunikasi. Keefektifan komunikasi akan memberi nilai harmonis bagi penutur bahasa.

Berdasarkan hal tersebut, rumusan masalah penelitian ini ialah "Bagaimanakah tinjauan secara ontologis, epistemologi, dan aksiologi dari tindak tutur?" Tujuan penelitian ini ingin mendeskripsikan tindak tutur berdasarkan ketiag kajian tesebut. Adapun, di dalam penelitian ini digunakan metode kualitatif deskriptif dengan teknik studi pustaka. Peneliti mengkaji berbagai sumber pustaka dalam mengidentifikasi konsep tindak tutur dalam kajian filsafat bahasa.

\section{METODOLOGI}

Penelitian ini merupakan jenis penelitian kualitatif deskriptif tentang kajian tindak tutur secara ontologis, epistemologi, dan aksiologi. Terkait dengan penelitian kualitatif, Creswell dalam Emzir (2011: 9), terdapat beberapa alasan mengapa seseorang melakukan penelitian kualitatif, di antaranya ialah karena (I) dalam studi kualitatif, pertanyaan penelitian sering dimulai dengan bagaimana dan apa. Dengan demikian, permulaan tersebut memaksa masuk ke dalam topik yang mendeskripsikan apa yang sedang berlangsung; dan (2) menggunakan studi kualitatif karena perlu menyajikan suatu pandangan yang mendetail tentang topik tersebut. Selanjutnya, Moleong (2007: II) juga mengemukakan bahwa penelitian deskriptif menekankan pada data berupa kata-kata, gambar, dan bukan angka-angka yang disebabkan oleh adanya penerapan metode kualitatif. Jadi, penelitian kualitatif dilakukan berasaskan pada pandangan mengenai topik dan dalam kajiannya dideskripsikan dengan kata-kata atau kalimat detail sehingga. Data dalam penelitian ini ialah konsep tindak tutur secara ontologis, 
epistemologi, dan aksiologi. Teknik pengumpulan data dilakukan dengan studi kepustakaan. Studi kepustakaan dilakukan dengan mengkaji berbagai konsep mengenai hakikat, prosedural, dan manfaat dari suatu objek, yakni tindak tutur itu sendiri. Sugiyono mengatakan bahwa studi pustaka berkaitan dengan kajian teoretis dan berbagai referensi (2012; 291). Oleh karena itu, mengingat penelitian ini merupakan penelitian berdasarkan konsep kajian, studi pustaka layak diterapkan sebagai pisau analisis penelitian.

\section{HASIL DAN PEMBAHASAN}

\section{Tindak Tutur Dari Tinjauan Ontologi}

Mengkaji tindak tutur secara ontologi berarti mengkaji tindak tutur dari segi konsep hakikat, yakni konsep tuturan dan tindakan dalam berbahasa.

Penggagas awal ihwal tindak tutur ialah John Langshaw Austin. Austin mengungkapkan bahwa bahasa dapat digunakan untuk melakukan tindakan melalui perbedaan antara tindak tutur konstatif dan tindak tutur performatif. Perbedaan tindak tutur dari keduanya kemudian dipadankan dengan sebutan tindak tutur lokusi, ilokusi, dan perlokusi. Kemudian, ia menjelaskan bahwa tindak tutur lokusi ' kira-kira sama dengan pengujaran kalimat tertentu, yang sekali lagi sama dengan pengertian tradisional. Dalam memproduksi tindak tutur lokusi tentunya juga melakukan berbagai tindak tutur ilokusi, yakni tuturantuturan yang memiliki daya (konvensional) tertentu, yang akhirnya juga melakukan tindak tutur perlokusi, yaitu apa yang dihasilkan atau diperoleh dengan mengatakan sesuatu (1962: 5).

Lebih lengkapnya, austin mengatakan:

"To say something may be to do something, or in saying something we do something (and also perhaps to consider the different case in which by saying something we do something)" (1962: 91).

Dijelaskan bahwa untuk berkata sesuatu mungkin juga melakukan sesuatu, atau dalam mengatakan sesuatu kita melakukan sesuatu (dan mungkin juga untuk mempertimbangkan peristiwa yang berbeda di dalam mengatakan sesuatu kita melakukan sesuatu). Kemudian, Searle sebagaimana dikutip oleh Wijana dan Rohmadi mengatakan bahwa tindak tutur merupakan produk atau hasil dari suatu kalimat dalam kondisi tertentu dan merupakan satuan terkecil dari komunikasi linguistik yang dapat berwujud pernyataan, perintah, tanya, atau yang lainnya (2011: 195). Pengertian ini mengisyaratakan bahwa tindak tutur tidak dapat dipisahkan atau merupakan bagian dari komunikasi.

Austin mengkaji suatu ungkapan atau tuturan dari tiga sudut pandang. Ketiga sudut pandang itu menghasilkan tindak tutur lokusi, ilokusi dan perlokusi (1962: 103). Secara singkat, lokusi untuk menyatakan sesuatu, ilokusi selain dari mengatakan sesuatu, dan perlokusi merupakan efek atau pengaruh dari mengatakan sesuatu.

Sebagai contoh, bila seorang suami mengatakan "Bu, kopi saya habis." Kepada istrinya. Maka, dapat dipastikan respon istri ialah membuatkan kembali segelas kopi untuk si suami. Secara lokusi, tuturan 'Bu, kopi saya habis' berupa informasi yang ditujukan kepada mitra tutur. Namun, meski sifatnya ialah informasi, tuturan tersebut merupakan permintaan secara tidak langsung kepada mitra tutur untuk membuatkan kembali segelas kopi. Dan efek ibu membuatkan minuman tersebut disebut dengan tindak tutur perlokusi. Berdasarkan contoh tersebut, dapat diketahui bahwa secara fungsional, ketiga tindak tutur tersebut satu kesatuan.

Akan tetapi, meskipun ketiga bentuk tindak tutur di atas hampir selalu diperbincangkan dalam kajian komunikasi bahasa, namun yang paling banyak dikaji ialah tindak tutur ilokusi yang memiliki daya untuk menindakkan seseorang. Tindak tutur ilokusi merupakan tindak tutur yang selain menyatakan sesuatu juga melakukan sesuatu. Sesuatu yang dimaksud ialah berupa respon dalam bentuk tindakan.

Dalam tindak tutur ilokusi, Searle sebagaimana dikutip Saifudin (2019) membagi atas tindak tutur representatif, direktif, komisif, ekspresif, dan deklaratif. Yang dimaksud dengan tindak tutur (I) representatif merupakan tindak tutur yang mengikat penutur pada kebenaran proposisi yang dituturkan. Misalnya, menyatakan, mengklaim; (2) Tindak tutur direktif merupakan tindak tutur yang dimaksudkan untuk membuat mitra tutur melakukan tindakan. Misalnya, memerintah, meminta; (3) tindak tutur komisif merupakan tindak tutur yang mengikat penutur untuk melakukan tindakan selain tuturan. Misalnya, berjanji, bersumpah; (4) tindak tutur ekpresif merupakan tindak tutur yang berfungsi untuk menyatakan sikap secara psikologis terhadap suatu keadaan. Misalnya, meminta maaf, memberi ucapan selamat; Dan, (5) tindak tutur deklaratif merupakan tindak tutur yang menghubungkan penutur dengan kenyataan atau hal-hal yang melingkupinya. Misalnya, memecat, mengangkat. 


\section{Tindak Tutur Dari Tinjauan Epistemologi}

Mengkaji tindak tutur secara epistemologi berarti mengkaji tindak tutur dari segi konsep proses, prosedur, atau cara kerja tindak tutur tersebut dalam berbahasa.

Dalam bertindak tutur seseorang bukanlah sematamata memproduksi kalimat, menyatakan maksud, atau mengeskpresikan diri melalui tuturan semata, tetapi juga diikuti oleh tindakan-tindakan. Tindakan-tindakan sebagai pemaksud tuturan itulah yang disebut dengan tindak tutur.

Ini berarti setiap tuturan memiliki maksud atau tujuan. Maksud atau tujuan tersebut disampaikan secara beragam dengan melihat situasi yang melandasi. Kadang-kadang seseorang menyampaikan tuturan yang di dalamnya terkandung maksud secara langsung, kadang-kadang ia memilih tuturan yang tidak langsung. Pemilihan ini bukan tanpa sebab, tapi berdasarkan pertimbangan keberhasilan komunikasi.

Dalam bertindak tutur tutur, partisipan harus benarbenar melaksanakan apa yang menjadi maksud tuturannya atau tuturan lawan bicaranya. Hal ini dikarenakan tindak tutur menghendaki partisipan mampu berkontribusi secara sungguh-sungguh untuk keefektifan komunikasi dan interaksi.

Katakanlah ketika penutur mengatakan "Saya berjanji tidak akan menyontek lagi.", "Tolong buatkan saya kopi.", dan "Kamu saya pecat." Maka penutur dan mitra tutur harus melaksanakan dengan baik apa yang menjadi tuturannya. Pada tuturan "Saya berjanji tidak akan menyontek lagi." Maka penutur harus melaksanakan dengan sungguh-sungguh tuturannya dengan tidak akan menyontek lagi sampai kapanpun juga. Jikalau ia diketahui melanggar tuturannya. Maka, tindak tuturnya tidak dapat dibenarkan. Begitu juga pada tuturan "Tolong buatkan saya kopi." Harus direspon dengan baik oleh mitra tutur dengan membuatkan segelas kopi sebagaimana yang biasa dikehendaki penutur. Dalam konteks ini, mitra tutur selaku pembuat kopi pun harus menunjukkan dengan baik secara perilaku dalam memenuhi keinginan penutur. Pendeknya, ia tidak boleh menunjukkan halhal yang dirasa tidak baik di pandangan mata penutur dalam membuat minuman tersebut. Kemudian, tuturan "Kamu saya pecat." Bisa diucapkan oleh siapapun. Namun, daya tuturan tersebut akan tampak jika si penutur adalah orang yang berwenang untuk mengatakan hal tersebut terhadap orang yang bekerja kepadanya. Ini berarti tuturan itu berdaya ilokusi manakala diucapkan oleh seseorang yang memang layak atau memenuhi.
Mengenai hal ini, Austin sebagaimana dikemukan oleh Sunardi (20II) bahwa terdapat kondisi kesahihan di mana pertuturan itu dapat berjalan dengan baik. Konsidi tersebut merupakan syarat agar tuturan komunikasi yang berdaya ilokusi dapat terlaksana sebagaimana yang diharapkan. Syarat tersebut ialah: (I) harus ada prosedur konvensional yang memiliki efek konvensional tentang pelaksanaan suatu tindak tutursituasi dan orang-orang yang terlibat harus berkelayakan seperti yang dipersyaratkan dalam prosedur, (2) prosedur tersebut harus dijalankan secara benar dan lengkap, dan (3) orang-orang yang terlibat harus memiliki pikiran, perasaan, dan keinginan seperti yang ditegaskan dalam prosedur-jika ada konsekuensi tindakan, maka semua pihak yang terlibat harus melaksanakannya.

Jadi, jika syarat-syarat tersebut dilanggar atau terdapat salah satu syarat yang dilanggar, maka komunikasi tidak akan berjalan dengan baik sebagaimana adanya.

\section{Tindak Tutur Dari Tinjauan Aksiologi}

Mengkaji tindak tutur secara aksiologi berarti mengkaji tindak tutur dari segi konsep nilai atau manfaat tindak tutur tersebut dalam berbahasa.

Tindak tutur dianggap sebagai salah satu objek berbahasa yang penting untuk diketahui dalam menunjang keefektifan berkomunikasi. Baik penutur maupun mitra tutur dapat menata kata atau kalimat untuk strategi komunikasinya dan bahkan keduanya dapat memahami arti komunikasi dengan baik sebagaimana yang diharapkan oleh lawan bicara.

Tindak tutur merupakan bagian dari komunikasi. Komunikasi yang dilakukan haruslah komunikasi cerdas, yakni komunikasi yang memperhitungkan berbagai aspek yang melingkupinya. Partisipan, waktu, lokasi, tatanan sosial-kultural harus diperhitungkan saat seseorang berinteraksi. Sebab, bilamana komunikasi tidak mempertimbangkan hal-hal tersebut yang disebut dengan konteks komunikasi, maka komunikasi tidak akan berjalan secara efektif, bahkan tidak akan ada komunikasi antarpartisipan. Hal ini dinyatakan oleh Cummings bahwa konteks memainkan peranan penting dalam rekonstruksi argumen (2007: 6). Sehingga, bila penutur dan mitra tutur abai konteks, maka tidak akan terwujud tujuan yang dimaksudkan dalam pembicaraan.

Berdasarkan hal tersebut, dapat dimaknai jika pengetahuan mengenai tindak tutur dengan berbagai konteks yang melingkupinya memberikan manfaat kepada siapapun dalam menunjang keefektifan berkomunikasi.

Selain itu, jika pembelajaran bahasa memang benar diarahkan agar pembelajar terampil berkomunikasi baik 
secara lisan maupun tertulis. Maka, bagi pembelajar bahasa sangat penting belajar tindak tutur sebagai ihwal komunikasi secara nyata dalam situasi dan berbagai kondisi.

\section{KESIMPULAN}

Berdasarkan hasil kajian, dapat disimpulkan bahwa mengkaji tindak tutur secara filsafat berarti mengkaji tindak tutur secara ontologi, epistemologi, dan aksiologi. Secara ontologi berarti mengkaji tindak tutur dari segi konsep hakikat, yakni konsep tuturan dan tindakan dalam berbahasa. Mengkaji tindak tutur secara epistemologi berarti mengkaji tindak tutur dari segi konsep proses, prosedur, atau cara kerja tindak tutur tersebut dalam berbahasa. Dan, mengkaji tindak tutur secara aksiologi berarti mengkaji tindak tutur dari segi konsep nilai atau manfaat tindak tutur tersebut dalam berbahasa.

\section{UCAPAN TERIMA KASIH}

Ucapan terima kasih serta penghargaan setinggitingginya disampaikan kepada LPDP yang senantiasa memotivasi agar selalu produktif untuk berkontribusi terhadap perkembangan ilmu pengetahuan yang ada. Selain itu juga, rasa hormat dan apresiasi tak terhingga disampaikan kepada dosen Program Studi Ilmu Pendidikan Bahasa S3 Universitas Negeri Semarang yang kerap memberikan inspirasi dalam berbagai diskusi keilmuan termasuk dalam penulisan artikel ini.

\section{REFERENSI}

Austin, J. L. (1962). How to Do Things with the Words. Newyork: Oxford university Press.

Bahrum. (2013). Ontologi, Epistemologi, dan Aksiologi. Jurnal Wawasan Keislaman Sulesana, 8 (2), 3545.

Cummings, Louise. (2007). Pragmatik: Sebuah Perspektif Multidisipliner Terjemahan Eti Setiawati dkk.). Yogyakarta: Pustaka Pelajar.

Emzir. (20II). Metodologi Penelitian Kualitatif Analisis Data. Jakarta: Raja Grafindo Persada.

Moleong, L.J. (2007). Metodologi Penelitian Kualitatif. Bandung. Remaja Rosda Karya.

Panariban, Tagor. (2008). Paradigma Bahasa. Yogyakarta: Graha IImu.
Saifudin, Akhmad. (2019). Teori Tindak Tutur Dalam Studi Linguistik Pragmatik. Jurnal Bahasa, Sastra, dan Budaya LITE, I5 (I), I-I6.

Sugiyono. 2012. Metode Penelitian Kuantitatif Kualitatif dan R\&D. Bandung: Alfabeta.

Sunardi. 2011. Filsafat Analitis Bahasa dan Hubungannya Dengan Ilmu Linguistik Pragmatik. Jurnal Bahasa, Sastra, dan Budaya LITE, 7 (2), 64-83.

Suriasumantri, J.S. (20I0). Filsafat Ilmu. Jakarta: Pustaka Sinar Harapan.

Wijana, I Dewa Putu dan Rohmadi. (20II). Analisis Wacana Pragmatik: Kajian Teori dan Analisis. Surakarta: Yuma Pustaka.

Www.wikipedia.filsafatbahasa.org. 